\title{
STUDY OF CELL DEATH AND STAGES OF LEUKOCYTES APOPTOSIS IN PULMONARY TUBERCULOSIS PATIENTS WITH DIFFERENT ANTIMYCOBACTERIAL TREATMENTS
}

\author{
Olga S. SHEVCHENKO ${ }^{1}$, Oksana A. NAKONECHNA ${ }^{1}$, Liliia D. TODORIKO ${ }^{2 \bowtie}$, \\ Olga 0. HOVARDOVSKA ${ }^{1}$, Olga 0. POHORIELOVA ${ }^{1}$, Sergey B. VOLF ${ }^{3}$, \\ Olena V. PIDVERBETSKA ${ }^{2}$, Iryna Ya. MAKOYDA ${ }^{4}$, Victor I. SLYVKA ${ }^{2}$ \\ ${ }^{1}$ Kharkiv National Medical University, Kharkiv, Ukraine \\ ${ }^{2}$ Higher State Educational Establishment „Bukovinian State Medical University“, Chernivtsi, Ukraine \\ ${ }^{3}$ Educational Establishment „Grodno State Medical University“, Grodno, Republic of Belarus \\ ${ }^{4}$ Ivano-Frankivsk National Medical University, Ivano-Frankivsk, Ukraine
}

Received 09 Oct 2019, Accepted 07 Nov 2019

https://doi.org/10.31688/ABMU.2019.54.4.11

\section{Abstract}

The aim of the study was to evaluate the condition of cytoplasmic membranes of leukocytes and to study their viability, to determine the varieties and stages of cell death of leukocytes in patients with pulmonary tuberculosis treated by different schemes of antimycobacterial treatment.

Materials and methods. The study was performed on 30 patients with pulmonary tuberculosis: the $1^{\text {st }}$ group -12 patients treated by standard regimen with $1^{\text {st }}$ line drugs; the $2^{\text {nd }}$ group treated by individual regimen with $1^{\text {st }}$ and $2^{\text {nd }}$ line drugs.

Results. The analysis of cytoplasmic membranes of leukocytes in the blood of patients from the $1^{\text {st }}$ and the $2^{\text {nd }}$ group showed that the proportion of live intact cells was $71.05 \pm 3.66 \%$, that is lower by $20.75 \%$ from the results of control group. In the $2^{\text {nd }}$ group, the proportion of alive cells was lower by $12.9 \%$ than in the $1^{\text {st }}$ group $(\mathrm{p}<0.05)$. In the same time, the proportion of leukocytes on the late of apoptosis/necrosis, that have

\section{RÉSUMÉ}

Létude des types de la mort cellulaire et les stades de l'apoptose des leucocytes chez les patients atteints de la tuberculose pulmonaire aux différents programmes de traitement antimycobactérien

L'objectif. D'évaluer l'état des membranes cytoplasmiques des leucocytes et étudier leur viabilité, déterminer les variétés et les stades de la mort cellulaire des leucocytes chez des patients avec tuberculose pulmonaire traités par différents schémas de traitement antimycobactérien.

Matériaux et méthodes. L'étude a été réalisée sur 30 patients atteints de tuberculose pulmonaire: 1er groupe - 12 patients traités par un schéma thérapeutique standard avec des médicaments en ligne; 2-ème groupe- patients traités individuellement avec les médicaments de la gamme I et II. Le groupe témoin comprenait 12 donneurs en bonne santé. L'étude a été réalisée par la cytométrie en flux sur un cytomètre en 
deep damages of cell structure, was more than $10 \%$ higher than in the $1^{\text {st }}$ group $(\mathrm{p}<0.05)$.

Conclusions. A significant difference between the groups of patients in the proportion of absolutely alive leukocytes and cells on the late stage of apoptosis/necrosis can be a proof of higher activation of apoptosis process by individual treatment regimen that included $1^{\text {st }}$ and $2^{\text {nd }}$ line-drugs, compared with standard $1^{\text {st }}$ line regimen. The obtained data allow us to recommend the study of influence of different anti-tuberculous drugs and regimens on apoptosis process of immune-competent cells, to evaluate the efficacy of pulmonary tuberculosis treatment.

Keywords: tuberculosis, apoptosis, Annexin V, flow cytometry.

\section{List of abbreviations}

AMBT - antimycobacterial treatment

CD - Cluster of Differentiation /CD antigens

DNA - deoxyribonucleic acid

EDTA - ethylene diamine tetraacetic acid

IP - intensive phase

MTB - Mycobacterium tuberculosis

PS - phosphatidylserine

TB - tuberculosis

7AAD - 7-aminoactinomycin flux FACS Calibur avec addition de marqueurs CD45 +, KIT I, 7AAD de détection d'AnnexinV FITC.

Résultats. L'analyse de l'état des membranes cytoplasmiques des leucocytes dans le sang des patients atteints de tuberculose pulmonaire des groupes 1 et 2 a montré que la proportion de cellules vivantes intactes était de $71,05 \pm 3,66 \%$, ce qui est inférieur de $20,75 \%$ aux résultats du groupe témoin. L'analyse comparative des résultats entre les groupes 1 et 2 a montré une différence significative entre la quantité de cellules vivantes non impliquée dans le processus d'apoptose. Dans le 2-ème groupes, la proportion de cellules vivantes était inférieure de $12,9 \%$ à celle dans le ler groupe $(\leq<0,05)$. Dans le même temps, la proportion de leucocytes à la fin de l'apoptose / nécrose, qui ont des dommages profonds à la structure cellulaire, était supérieure de plus de $10 \%$ à celle du groupe $1(\leq<0,05)$. Les différences entre les proportions de leucocytes dans les autres stades de l'apoptose n'étaient pas significatives $(20,05)$.

Conclusion. Nos résultats suggèrent que le traitement de la tuberculose pulmonaire s'accompagne d'une externalisation de la phosphatidylsérine dans la foliole phospholipidique de la membrane plasmique des leucocytes CD-45 +. Une différence significative entre les groupes de patients dans la proportion de leucocytes et de cellules absolument vivants au dernier stade de l'apoptose / nécrose peut être une preuve de l'activation plus élevée du processus d'apoptose par les schémas thérapeutiques individuels incluant les médicaments de Ière et de IIème lignes, par rapport au schéma thérapeutique standard I. Les données obtenues nous permettent de recommander l'étude de l'influence de différents médicaments antituberculeux et de schémas thérapeutiques sur le processus d'apoptose des cellules immunocompétentes afin d'évaluer l'efficacité du traitement de la tuberculose pulmonaire.

Mots clés: la tuberculose, l'apoptose, Annexine V, cytométrie en flux.

and genetically regulated process, activated as a response to cell stress or metabolic disorders ${ }^{8-10}$. In the system «host-organism» - «organism-pathogen», apoptosis has three pathogenic roles: apoptosis as a mechanism of elimination of "host's» cells; apoptosis as an inductor of inflammation process; apoptosis as mechanism of protection of "host-organism» ${ }^{8}$. Depending on the efficacy of realization of these roles, cell death has an influence on immunity, the result of the infection process, course and outcome of the treatment.

Among infectious diseases, tuberculosis (TB) has a leading position in the main epidemiological indicators - morbidity, mortality, prevalence ${ }^{11}$. Some recent studies focused on the importance of better 
understanding of cell death in TB patients, as a chance to improve safety and efficacy of antimycobacterial treatment $(\mathrm{AMBT})^{12-14}$. The creation of host-directed treatment regimen is gaining considerable interest, because of the emergence of drug-resistant strains of MTB as response to the standard therapy.

The effect of AMBT on the functional activity of «hosts-organism» cells, by the disorganization of their membrane structures, is well-known ${ }^{4}$. One study showed that destruction of regulation of apoptosis is a risk factor for development or progression of TB disease ${ }^{12}$. The role of immunocompetent cell's apoptosis in TB is favorable for organism, because it eliminates Mycobacterium tuberculosis (MTB) located inside cell and activates native and adapted immune response of «host-organism». In the same time, necrosis has a destructive effect and allows to spread MTB and increase MTB-population ${ }^{15-17}$.

Anti-TB immunity differs from immunity to other infections. Immune response depends on the phagocytosis by blood cells, formation of specific antibodies and delayed-type hypersensitivity; all these processes are performed or depend on leukocytes. Thus, study of apoptosis process in TB patients has high practical and theoretical interest.

THE AIM OF THE STUDY was to evaluate the condition of cytoplasmic membranes of leukocytes and to study their viability, to determine the varieties and stages of cell death of leukocytes in patients with pulmonary tuberculosis treated by different schemes of antimycobacterial treatment.

\section{Materials AND Methods}

The study was performed on 30 patients with diagnosis of pulmonary TB, who were treated at the Regional Tuberculosis Hospital $\mathrm{N}^{\circ} 1$ (Kharkiv, Ukraine). All diagnosis and treatment were prescribed according to the order of the Ministry of Health of Ukraine No. 620 of 14. 09. 2014. Patients were divided into groups depending on the profile of resistance of MTB detected in sputum assay and regimen of AMBT that was prescribed according to it. The first group included 12 patients with sensibility to anti-TB drugs, who were treated by standard treatment regimen, using only $1^{\text {st }}$ line drugs (2-4 months of intensive phase with daily use of Isoniazid (INH), Rifampicine (RIF), Pyrozinamide, Etambutol; 4 months of continuation phase with daily use of Isoniazid and Rifampicine). The second group included 18 patients with detected phenotypical resistance of MTB to INH, who received treatment by individual regimen with $1^{\text {st }}$ and $2^{\text {nd }}$ line anti-TB drugs $(2$ months daily using of RIF, Pyrozinamide, Fluoroquinolone,
Kanamicin; 10 months - Rifampicine, Pyrozinamide, Fluoroquinolone). The control group consisted of 12 healthy donors.

The characteristics of groups: average age in the $1^{\text {st }}$ group was 35.8 years, in the 2 nd group - 42.9 years, in the control group - 39.9 years. In the $1^{\text {st }}$ group, firstly diagnosed TB cases were registered in $83.3 \%$ and recurrent cases in $16.6 \%$; in the $2^{\text {nd }}$ group $-77.8 \%$ and $22.2 \%$, respectively. All cases were proved by positive cultures method, provided on the liquid media on MGIT BACTEC-960 and/or on Löwenstein-Jensen solid media. According to the results of drug susceptibility testing, mono- or poly resistance of MTB to the anti-TB drugs was established in $43.4 \%$ of the patients of the $1^{\text {st }}$ group and $46 \%$ of the patients of the $2^{\text {nd }}$ group. According to radiological investigation, the destruction of pulmonary tissue was encountered in $77.7 \%$ and $94 \%$ of patients, respectively, from the $1^{\text {st }}$ and $2^{\text {nd }}$ groups. In the $1^{\text {st }}$ group, $96.6 \%$ of patients and $78 \%$ of the $2^{\text {nd }}$ group had infiltrative clinical form of TB, the others - disseminated $\mathrm{TB}$.

The biomaterial for the study was blood collected from the peripheral vein in the morning, in a volume of $10 \mathrm{ml}$ and placed in an EDTA tube. Biomaterials were collected at the end of IP of AMBT. The study of viability of blood leukocytes, as well as varieties and stages of cell death were performed by flow cytometry using a FACS Calibur flow cytometer. The assessment of the stages of cell death was performed by adding the markers CD45 + , AnnexinV FITC detection KIT I, 7AAD (Becton Dickinson, USA) ${ }^{6}$. A marker of late-stage apoptosis and/ or necrosis is 7-aminoactinomycin (7AAD), a vital DNA-dye that penetrates the cell in violation of cell membrane integrity. AnnexinV FITC is a marker of early-stage apoptosis, which is a Ca2+-dependent phospholipid binding protein. AnnexinV connects with cells that have PS. Assessment of cells death stages was performed by adding markers CD45+, AnnexinV FITC detection KIT I, 7AAD. Four stages of cells were determined by this method: 1- live cells $\left(\mathrm{AnnexinV}^{-}, 7 \mathrm{AAD}^{-}\right), 2$ - apoptotic cells in initial stage $\left(\mathrm{AnnexinV}^{+}, 7 \mathrm{AAD}^{-}\right)$, 3-apoptotic/necrotic cells in late stage $\left(\mathrm{AnnexinV}^{+}, 7 \mathrm{AAD}^{+}\right)$, 4- dead necrotic cells $\left(\mathrm{AnnexinV}^{-}, 7 \mathrm{AAD}^{+}\right)$. The results of flow cytometry were assessed by using the program CELL Quest Pro (Becton Dickinson, USA) «WinMDIVersion 2.9».

Statistical processing of the obtained results was carried out by Microsoft Excel 2016 (license № 00201-10554-16848-AA351) and Stat soft Statistica 8.0. (license STA862D175437Q). Significant differences were considered to be at a $\mathrm{p}$ value $<0.05$.

The work was performed according to the requirements of the Statute of Ukrainian Association 
Table 1. Quantity of CD-45+ cells in different stages of cell death in the blood of tuberculosis patients and healthy donors

\begin{tabular}{ccc}
\hline $\begin{array}{c}\text { States } \\
\text { of leukocytes }\end{array}$ & TB patients & Healthy donors \\
\hline Alive cells (AnnexinV-7AAD $\left.{ }^{-}\right)(\%)$ & $71.05 \pm 3.66^{*}$ & $91.8 \pm 0,1$ \\
\hline $\begin{array}{c}\text { Initial stage of apoptosis } \\
(\text { AnnexinV+7AAD })(\%)\end{array}$ & $14.77 \pm 1.47^{*}$ & $3.85 \pm 0.16$ \\
\hline $\begin{array}{c}\text { Late stage of apoptosis/necrosis } \\
(\text { AnnexinV+7AAD+) }(\%)\end{array}$ & $12.35 \pm 2.36^{*}$ & $3.08 \pm 0.3$ \\
\hline Dead necrotic cells (AnnexinV+7AAD+)(\%) & $0.95 \pm 0.07^{*}$ & $1.78 \pm 0.32$ \\
\hline -significantly differ when comparing with control group $(\mathrm{p}<0.05)$ &
\end{tabular}

Table 2. Quantity of CD-45+ cells in different stages of cell death in the blood of tuberculosis patients with different treatment schemes of antimycobacterial treatment

\begin{tabular}{cccc}
\hline $\begin{array}{c}\text { States } \\
\text { of leukocytes }\end{array}$ & $1^{\text {st }}$ group & $2^{\text {nd }}$ group & Control group \\
\hline Alive cells $\left(\right.$ AnnexinV $\left.^{-} 7 \mathrm{AAD}^{-}\right)(\%)$ & $74.59 \pm 3.88^{*} \#$ & $61.63 \pm 6.57^{*} \#$ & $91.8 \pm 0.1$ \\
\hline $\begin{array}{c}\text { Initial stage of apoptosis } \\
(\text { AnnexinV+7AAD })(\%)\end{array}$ & $13.71 \pm 1.82^{*}$ & $17.6 \pm 1.72^{*}$ & $3.8 \pm 0.16$ \\
\hline $\begin{array}{c}\text { Late stage of apoptosis/necrosis } \\
(\text { AnnexinV+7AAD+) } \%)\end{array}$ & $9.56 \pm 2.04^{*} \#$ & $19.8 \pm 5.04^{*} \#$ & $3.1 \pm 0.3$ \\
\hline Dead necrotic cells (AnnexinV+7AAD+) (\%) & $0.9 \pm 0.1^{*}$ & $1.07 \pm 0.03$ & $1.8 \pm 0.31$ \\
\hline
\end{tabular}

*-significantly differ when comparing with control group $(\mathrm{p}<0.05)$

\#--significantly when comparing the two groups $(p<0.05)$

for Bioethics and the GCP norms (1992), requirements and norms of ICH GLP (2002), typical ethics provisions of the Ministry of Public Health of Ukraine 66 dated February 13, 2006.

\section{Results}

The analysis of cytoplasmic membranes of leukocytes in the blood of pulmonary TB patients of the $1^{\text {st }}$ and $2^{\text {nd }}$ groups showed that the proportion of live intact cells was $71.05 \pm 3.66 \%$, that is lower by 20.75 $\%$ from the results of the control group. The proportion of apoptotic cells that reacted with Annexin $\mathrm{V}^{+}$ was significantly higher $(p<0.05)$ in the groups of TB patients than in the control group and the average value for $\mathrm{TB}$ patients was $27.1 \pm 1.9 \%$. The increasing of quantity of apoptotic cells in the blood of TB patients was defined in both apoptosis stages. In the early stage, it was higher by 3.8 times, in the late stage by 5.3 times, compared with control group. The proportion of dead necrotic cells in the blood of TB patients was decreased by 1.8 times. All detected parameters were significantly $(\mathrm{p}<0.05)$ different from the control group. The results are presented in Table 1.

The comparative analysis of the results of flow cytometry, with assessment of state leukocyte's cytoplasmic membranes between the $1^{\text {st }}$ and $2^{\text {nd }}$ groups, showed a significant difference between the amounts of alive cells not involved in the apoptosis process. In the $2^{\text {nd }}$ group, the proportion of alive cells was lower by $12.9 \%$ than in the $1^{\text {st }}$ group $(\mathrm{p}<0.05)$. In the same time, the proportion of leukocytes on the late of apoptosis/necrosis, that have deep damages of cell structure, was higher by more than $10 \%$ than in the $1^{\text {st }}$ group $(p<0.05)$. The differences between the proportion of leukocytes in other stages of apoptosis were not significant $(\mathrm{p} \geq 0.05)$. The results are presented in Table 2 .

The greatest decline of leukocytes viability was detected in the $2^{\text {nd }}$ group, compared with control indicators, by more than 15\%. This difference can be observed in Fig. 1, that presents typical cytograms with vizualisation of states of leukocytes in the blood of TB patients from the $2^{\text {nd }}$ group (2b) and healthy donors $(2 \mathrm{a})$.

\section{Discussion}

The surface of healthy cells is composed of lipids that are asymmetrically distributed on the inner and outer leaflet of the plasma membrane. Phosphatidylserine (PS) is one of these lipids that is normally restricted to the inner leaflet of the plasma membrane, therefore only exposed to the cell cytoplasm. However, during apoptosis, lipid asymmetry is lost and PS becomes exposed on the outer leaflet of 
2a:

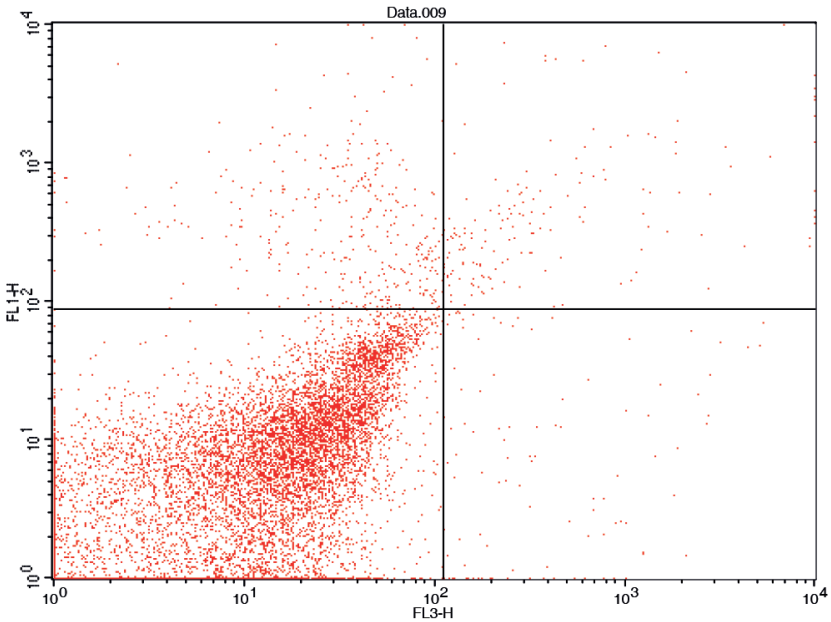

Quadrant Statistics

X Parameter: FL3-H (Log)

Y Parameter: FL1-H (Log)

\begin{tabular}{cr} 
Quad & $\%$ Gated \\
\hline UL & 3.47 \\
UR & 1.59 \\
LL & 93.96 \\
LR & 0.97
\end{tabular}

2b:

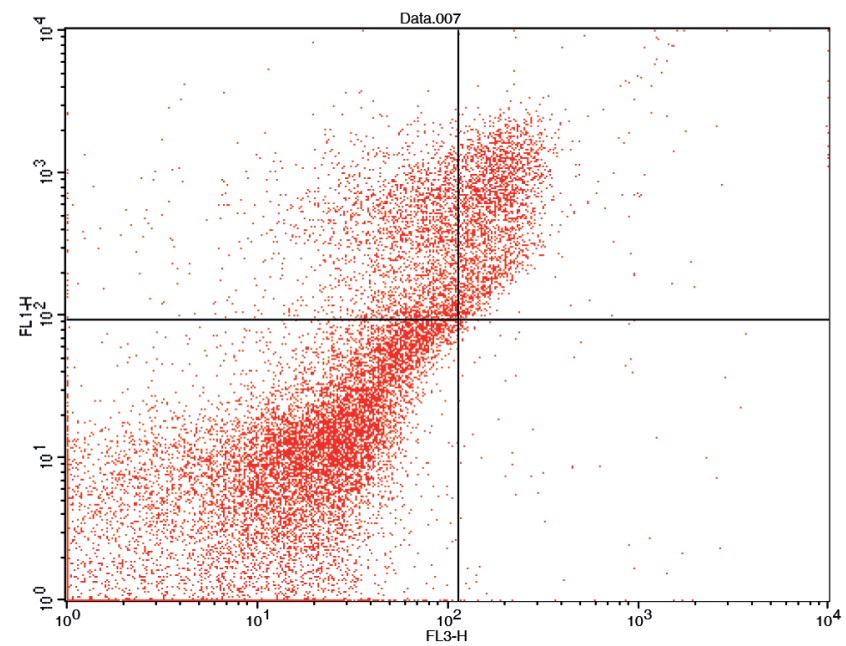

Quadrant Statistics

X Parameter: FL3-H (Log)

Y Parameter: FL1-H (Log)

Quad \% Gated

UL 14.22

UR $\quad 13.35$

LL $\quad 71.93$

LR $\quad 0.50$

Figure 1. Flow cytometric pattern with vizualisation of states of leukocytes in the blood of healthy donor (2a) and TB patient of the $2^{\text {nd }}$ group ( $2 b$ )

the plasma membrane ${ }^{18}$. The modern method of flow cytometry gives the ability to detect externalization of PS to cell cytoplasmic membrane, that is a sign of early apoptosis ${ }^{10}$. PS, located on the outer leaflet of the plasma membrane of apoptotic cells, connects with Annexin- $\mathrm{V}$. The relations of apoptosis and TB infection/disease are actively discussed in contemporary publications that present the results of experimental and clinical studies. However, data do not allow to clarify the role of apoptosis in the development, progression and outcome of TB.

The study of proapoptotic factor - expression of CD-95+ on the lymphocytes of blood in patients with abdominal TB showed the increasing of CD-95+ by 1.8 times, that demonstrated the association of chronic inflammation with elevated readiness of cells to apoptosis ${ }^{19}$. Other study of the content of CD-95+ cells in the blood of patients with drug-resistant TB and $\mathrm{TB}$ with saved sensitivity to anti-TB drugs before the start of specific treatment did not differ from the results of healthy donors. It was found that in patients with drug-resistant TB the number of apoptotic Annexin $\mathrm{V}^{+}$cells was higher than in patients without resistance ${ }^{20}$. Usually, the authors consider that TB caused by drug-resistant strains of MTB is accompanied by deeper impaired immune defense mechanisms, including the ability of cells to activate. This trend is confirmed by the results of our study. Because the study was conducted during AMBT, other reasons for indicated differences can be the progression of the disease or the utilization of different therapeutic regimens.

Information about the influence of anti-TB drugs on apoptosis of immune-competent cells is already known. For example, an experimental study of INH effect on cell death determined that INH 
directly causes cell death in antigen-specific $\mathrm{T}$ cell (matched by CD-4+), that leads to immune impairment and increases the risk of reinfection or reactivation of $\mathrm{TB}^{21}$. A study with INH-resistant MTB indicated that INH affected TNF-alpha release, resulting in the reduction of macrophages apoptosis and intracellular INH-resistant MTB viability ${ }^{22}$. In our study, the patients from the $2^{\text {nd }}$ group, with resistance to INH, did not take INH in AMBT. Nonetheless, other effective and widely used anti-TB drug, RIF, demonstrated a reverse effect - RIF has an ability to inhibit anti-CD-95-inducted apoptosis in Jurkat T-cells by modulating the expressions of various molecules regulating apoptosis and its effect appears to be mediated via glucocorticoid receptors $^{23}$.

The clinical study determined that TB is accompanied by an alteration of the functional activity and restructuring of membranes of mononuclear of peripheral blood. The membrane destructive effect of AMBT on mononuclear of peripheral blood results in disorganization of their membranes, manifesting in accumulation of lysophospholipids, with simultaneous decreasing of the content of phosphatidylserine and phosphatidylcholine. The toxic effect of AMBT has no effect on the number of monocytes in peripheral blood. Disorganization of the membrane structures of these cells and the possible suppression of their functional activity occur?

\section{Conclusions}

Our results suggest that treatment of pulmonary tuberculosis is accompanied by the externalization of phosphatidylserine in the phospholipid leaflet of the plasma membrane of CD-45+ leukocytes. We can suppose that anti-tuberculosis drugs can be inductors of leukocytes apoptosis, because the proportion of absolutely alive and functional leukocytes is lower by $20.75 \%$ in the blood of TB patients than in practically healthy donors. The significant difference between the groups of patients in the proportion of absolutely alive leukocytes and cells on the late stage of apoptosis/necrosis can be a proof of higher activation of apoptosis process by individual treatment regimen that included $1^{\text {st }}$ and $2^{\text {nd }}$ line drugs, compared with standard regimen. The obtained data allow us to recommend the study of influence of different anti-tuberculosis drugs and regimens on apoptosis process of immune-competent cells, to evaluate the efficacy of anti-tuberculosis drugs, schemes and pulmonary tuberculosis treatment.

\section{Compliance with Ethics Requirements}

"The study was performed according to the requirements of the Statute of Ukrainian Association for Bioethics and the GCP norms (1992), requirements and norms of ICH GLP (2002), ethical standards in the Helsinki Declaration of 1975, as revised in 2008, typical ethics provisions of the Ministry of Public Health of Ukraine 66 dated February 13, 2006. The work was approved by Ethical Commission of Kharkiv National Medical University, Ukraine (Protocol No 2 of 03.02.2016; chairmen - MD, professor Ospanova T.S. (+ 38050 9988242))"

„The authors declare no conflict of interest regarding this article"

"Informed consent was obtained from all the patients included in the study"

"No funding for this study"

\section{Acknowledgements}

No acknowledgements

\section{References}

1. Chernushenko EF, Protsyuk RG. Anti-tuberculosis immunity (Part 1). Ukrainian Pulmonology Journal. 2010; (4):53-58.

2. Chernushenko EF, Protsyuk RG. Anti-tuberculosis immunity (Part 2). Ukrainian Pulmonology Journal. 2011; (1):29-32

3. Garib FYu, Rizopulu AP. Interactions of pathogenic bacteria with innate immune reactions of host. Infektsiya i immunitet. 2012; 2(3):581-590.

4. Iftimie $G$, Bratu OG, Socea B, et al. Pulmonary involvement in rheumatoid arthritis - another face of the coin. Arch Balk Med Union 2018;53(1):89-95.

5. Paraschiv B, Dediu G, Iancu A, Bratu O, Diaconu C. Superior vena cava syndrome - review. Arch Balk Med Union 2017;52(1):39-43.

6. Ryasensky DS, Aseev AV, Elgali AI. The state of membranes of mononuclear leukocytes in patients with tuberculosis of lungs. Klin Lab Diagn. 2018; 63(5):301-305.

7. Diaconu C, Balaceanu A, Morosan E. Sepsis biomarkers: past, present and future. Farmacia 2015;63(6):811-815.

8. Somova LM, Besednova NN, Plekhova NG. Apoptosis and infectious diseases. Infection and immunity $(U k r)$. 2014; 4(4):303-318

9. Koopman G, Reutelingsperger CP, Kuijten GA, et al. Annexin $\mathrm{V}$ for flow cytometric detection of phosphatidylserine expression on B cells undergoing apoptosis. Blood. 1994; 84(5):1415-1420

10. Mohareer K, Asalla S, Banerjee S. Cell death at the crossroads of host-pathogen interaction in Mycobacterium tuberculosis infection. Tuberculosis (Edinb). 2018;113:99-121

11. WHO Global tuberculosis report 2018 Geneva: World Health Organization; 2018.

12. Elliott TO, Owolabi O, Donkor S, et al. Dysregulation of apoptosis is a risk factor for tuberculosis disease progression. J Infect Dis. 2015; 212(9):1469-1479

13. Liu $\mathrm{CH}$, Liu H, Ge B. Innate immunity in tuberculosis: host defense vs pathogen evasion. Cell Mol Immunol. 2017;14(12):963-975

14. Pahari S, Negi S, Aqdas M, Arnett E, Schlesinger LS, Agrewala JN. Induction of autophagy through CLEC4E in 
combination with TLR4: an innovative strategy to restrict the survival of Mycobacterium tuberculosis. Autophagy. 2019;1-23

15. Fratazzi C, Arbeit RD, Carini C, et al. Macrophage apoptosis in mycobacterial infections. J Leukoc Biol. 1999; 66(5):763-764

16. Lam A, Prabhu R, Gross CM, Riesenberg LA, Singh V, Aggarwal S. Role of apoptosis and autophagy in tuberculosis. Am J Physiol Lung Cell Mol Physiol. 2017;313(2):L218-L229.

17. Todoriko LD, Yeremenchuk IV, Davydenko IS. Study of proliferative activity and intensity of bronchial epitheliocytes apoptosis in case of pulmonary multidrug-resistant tuberculosis. Tuberculosis, Lung Diseases, HIV Infection (Ukr). 2015; $4(23): 42-47$

18. Todoriko LD, Yeremenchuk IV, Fedirtsan MP, Kiril AO, Savchuk OV, Golovachuk OV. Indicators of cytokine regulation and pathogenetic ground for applying of Tivortin in patients with multidrug-resistant pulmonary tuberculosis. Natural and Technical Science. 2017; 13(121):54-56

19. Akimova V.M. CD95 Expression on peripheral blood lymphocytes in acute and chronic abdominal diseases expression on peripheral blood lymphocytes in acute and chronic abdominal diseases. Modern Problems of Science and Education (Rus). 2014;(1):127-135

20. Kononova TYe, Urazova OI, Novitsky VV, Churina YeG, Ignatov MV. Peculiarities of immune reaction in patients with drug-resistant pulmonary tuberculosis. $V$ Bulletin of Siberian Medicine, 2012(4):160-162

21. Tousif S, Singh DK, Ahmad S, et al. Isoniazid induces apoptosis of activated CD4+ T cells: implications for post-therapy tuberculosis reactivation and reinfection. J Biol Chem. 2014;289(44):30190-195

22. Wibawa T, Pangemanan L, Rachmawaty FJ, Rintiswati N, Mustofa, Soesatyo MH. Isoniazid (INH) treatment of INH-resistant Mycobacterium tuberculosis inhibits infected macrophage to produce TNF-alpha. Southeast Asian J Trop Med Public Health. 2014;45(5):1107-1113.

23. Yerramasetti R, Gollapudi S, Gupta S. Rifampicin inhibits CD95-mediated apoptosis of Jurkat T cells via glucocorticoid receptors by modifying the expression of molecules regulating apoptosis. J Clin Immunol. 2002; 22(1):37-47. 